\title{
.HOW CLASSIFY MISTAKES AND SHORTCOMINGS IN REVIEWS OF SPECIAL AND SCIENTIFIC WORKS
}

\author{
Ján STOFFA - Veronika STOFFOVÁ
}

\begin{abstract}
The study presents an original and universal proposal of classification of mistakes and shortcomings in reviews of special and scientific works. The classification follows from the generally accepted requirement that the reviewer of a special or scientific work has to appreciate all significant positive values of the work as well as to point out all significant mistakes and shortcomings of it. The informational value and scientific truth of presented information and also respecting of copyright and scientific ethics were accepted as base criterions of classification. Each reviewer has to point out all key and other essential mistakes and shortcomings in fulfilling the criteria. Mistakes and shortcomings should be ordered not sequentially but characterized in category groups with presenting some representatives from each group as examples. Didactical mistakes and shortcomings and that ones which are not connected with distortion of information he/she should point out only from educational viewpoint.
\end{abstract}

Key words: reviews of special and scientific works, shortcomings of special and scientific works.

\section{AKO KLASIFIKOVAŤ CHYBY A NEDOSTATKY V POSUDKOCH ODBORNÝCH A VEDECKÝCH PRÁC}

Resumé: Štúdia prináša originálny a univerzálny návrh klasifikácie chýb a nedostatkov v posudkoch odborných a vedeckých prác. Klasifikácia vychádza zo všeobecne akceptovanej požiadavky, že posudzovatel' odbornej alebo vedeckej práce je povinný kladne ocenit' všetky podstatné pozitívne hodnoty, ale rovnako poukázat' aj na všetky podstatné chyby a nedostatky v nej. Ako základné klasifikačné kritériá boli prijaté informačná hodnota a vedecká pravdivost' prezentovaných informácií a tiež dodržanie autorského práva a vedeckej etiky. Každý posudzovatel' by mal v svojom posudku poukázat' predovšetkým na všetky klúčcové a podstatné chyby a nedostatky pri naplnení týchto kritérií. Chyby a nedostatky by nemal uvádzat' v poradí ich výskytu, ale po kategoriálnych skupinách s uvedením reprezentatívnych príkladov. Na chyby a nedostatky, pri ktorých nedochádza k skresleniu informácie, alebo na didaktické chyby a nedostatky by mal poukázat' len z edukačných dôvodov.

Kl'účové slová: odborné posudky, nedostatky odborných a vedeckých prác.

\section{1 Úvod}

Počas svojej odbornej pracovnej dráhy sa každý odborník skôr alebo neskôr ocitne v role posudzovatel'a odbornej, príp. vedeckej práce. Tieto práce spravidla predstavujú dokumenty rôzneho charakteru od nepublikovanej písomnej práce k odbornej skúške až po vedeckú monografiu. Kým na neškolských pracoviskách sa adept dostáva k posudzovaniu o niečo neskôr, na vysokoškolských pracoviskách sa $\mathrm{k}$ tejto role dostáva už krátko po absolvovaní vysokej školy, ked' posudzuje bakalárske či magisterské práce. Už samo poverenie posudzovat' prácu iného autora predstavuje nielen prejav istej dôvery odbornej komunity $\mathrm{k}$ designovanému posudzovatel'ovi, ale aj závažnú spoločenskú objednávku. Ak jej naplnenie prispieva k posilneniu autority posudzovatel'a, jej nenaplnenie, naopak, ju znižuje, ba nekvalitne spracovaný posudok môže odhalit' aj rôzne nedostatky v odbornej erudícii posudzovatel'a.

O rôznych aspektoch odbornej a vedeckej práce bolo u nás i v zahraničí napísaných mnoho publikácií. V tých, s ktorými sme sa mali možnost' zoznámit', sme však nenašli smerodajné poučenie pre posudzovatel'ov odborných a vedeckých prác napriek tomu, že ich úloha je nespochybnitel'ná. Preto sú posudzovatelia, najmä tí mladší, často odkázaní len na seba, prípadne na vzory posudkov, s ktorými sa stretli v svojej predchádzajúcej praxi. Naše mnohoročné skúseností z vypracovania alebo preštudovania rádovo tisícov odborných posudkov na rôzne účely nás oprávňujú zovšeobecnit' tieto skúsenosti a v ucelenej forme prezentovat' náš originálny a univerzálny návrh na usporiadanie 
tej obligatórnej časti posudkov, ktorá sa týka chýb a nedostatkov posudzovaných prác. Jej ciel'om je podat' pomocnú ruku všetkým, ktorí majú problémy s vypracovaním tejto časti posudku. Jednotlivé triedy chýb a nedostatkov sa v príspevku vyčleňujú len rámcovo. Čitatel'a, ktorý sa bližšie zaujíma o konkrétne chyby a nedostatky odkazujeme na štúdie (1) až (6).

\section{Všeobecné pravidlá pre písanie oponentských posudkov}

Všeobecné pravidlá pre písanie oponentských posudkov možno zhrnút' do nasledovných bodov.

- Spracovatel' posudku sa musí snažit' o maximálnu objektivitu;

- Posudok má zhodnotit' posudzované dielo komplexne;

- Posudok nemá obsahovat' opis posudzovaného diela (rozsah, členenie atd'.), ale má obsahovat' jeho mnohostrannú analýzu;

- V posudku má byt' explicitne uvedené č posudzované dielo obsahuje nové poznatky a v prípade dizertačných prác, či práca je dizertabilná;

- Ak práca má explicitne stanovené ciele, posudzovatel' sa má vyjadrit' nielen o ich aktuálnosti, náročnosti, adekvátnosti, ale aj o tom či a v akej miere boli dosiahnuté;

- Ak ide o kvalifikačnú prácu, posudzovatel' sa má explicitne vyjadrit', či predložená práca spĺn̆a stanovené kritéria kvality $\mathrm{z}$ hl'adiska obsahu a formy spracovania a miery dosiahnutia ciel'ov práce a či prácu odporúča k obhajobe;

- Kritika obsiahnutá v posudku má byt' neosobná: kritizujú sa chyby a nedostatky diela a nie ich autor;

- Je neracionálne uvádzat' chyby a nedostatky posudzovaného diela $\mathrm{v}$ tom poradí, ako sa $\mathrm{s}$ nimi posudzovatel' stretáva $\mathrm{v}$ rukopise. Tak si ich posudzovatel' môže poznačit', ale v posudku by ich mal štrukturalizovat' do uvedených tried;

- Posudzovatel' by mal vytýkat' len tie chyby a nedostatky, o ktorých si je absolútne istý. Nie je racionálne vytýkat' diskutabilné chyby a nedostatky, prípadne dovolené alternatívne riešenia, ktoré posudzovatel' nepoužíva;

- Osobitnú pozornost' by mal posudzovatel' venovat' neologizmom, $z$ ktorých mnohé podliehajú adaptačným zmenám, príp. môžu mat' viaceré alternatívne formy;
- Posudzovatel' má vychádzat' zo zásady, že autor posudzovanej práce je $\mathrm{v}$ plnej miere zodpovedný za jej obsah aj formu, s výnimkou tých iformácií, ktoré prevzal auteticky z citovaných informačných zdrojov;

Posudzovatel' by mal vykonat' dôslednú korektúru rukopisu posudku, aby sa $\mathrm{v}$ ňom nevyskytli chyby a nedostatky, ktoré vytýka posudzovanému. Množina možných nedostatkov a chýb je nevyčerpatel'ná a v prípade konkrétnych posudzovaných prác môže mat' vel'mi odlišnú skladbu. Z tejto množiny však možno vyčlenit' niekol'ko skupín charakterom príbuzných nedostatkov a chýb, ktoré sú predmetom d'alších článkov tejto štúdie.

Ide o kategóriu kl'účových nedostatkov a chýb, kategóriu závažných vecných chýb a nedostatkov, kategóriu chýb a nedostatkov, ktoré nevedú k stratám informácie, kategóriu formálnych chýba a nedostatkov a v prípade edukačne orientovaných práca aj o kategóriu didaktických chýb a nedostatkov. V prípade každej kategórie sa ako príklady uvádzajú často sa opakujúce chyby a nedostatky.

\section{Kategória kl’účových chýb a nedostatkov}

$\mathrm{Z}$ množiny možných chýb a nedostatkov ako klúčové možno vyčlenit:

1. Výber nesprávnej, príp. neoptimálnej metódy výskumu;

2. Nesplneniedodržanie predpokladov na použitie zvolenej výskumnej metódy;

3. Riešenie neaktuálnej témy;

4. Opakované riešenie už vyriešeného problému;

5. Preukázatel'né plagiátorstvo;

6. Nesprávna interpretácia dosiahnutých výsledkov výskumu;

7. Závažné tvrdenia a formulácie odporujúce pravidlám formálnej logiky;

8. Vecne nepodložené zovšeobecnenia a závery;

9. Výskumom nepodložené, príp. inak nedokázané závery;

10.Nekritické preberanie inormácií, správnost' a pravdivost' ktorých je očividná alebo spochybnitel'ná;

11.Nesúlad medzi názvom posudzovanej práce a jej obsahom.

Každý z uvedených dôvodov je dostatočný pre negatívne hodnotenie posudzovanej práce.

\section{Kategória závažných vecných chýb a nedostatkov}


Do tejto kategórie možno zaradit' vel'ké množstvo rôznorodých chýb a nedostatkov. Ako príklady možno uviest':

- Chyby v definíciách klúčových pojmov;

- Nevyváženost', nejednoznačnost', neaktuálnost' a nejednotný spôsob definícií základných pojmov;

- Použitá definícia nevyjadruje obsah pojmu pomenovaného daným termínom;

- Použitie nenáležitých, príp. nejednoznačných termínov;

- Pri uvádzaní vymenovaní a porovnávaní rôznych definícií autor sa nevyjadrí $\mathrm{k}$ ich exaktnosti, príp. sa nevyjadrí, ktorú považuje za správnu a úplnú a prečo.

- Pri zostavovaní jednotlivých zoznamov sa neuplatňuje systémový prístup;

- Pri triedeniach a vytváraní skupín sa neuvádzajú alebo striedajú, príp. nenáležite kombinujú kritéria triedenia;

- Hrubé chyby vo výpočtoch;

- Použitie nevysvetlených, príp. nejednoznačných skratiek, značiek, symbolov;

- Použitie nezákonných jednotiek bez ich prepočtu na jednotky SI;

- Absencia povinných údajov v bibliografických odkazoch;

- Použitie nespisovných slov a termínov;

- Nepoužívanie národných ekvivalentov medzinárodných alebo cudzích termínov;

- Chyby prameniace zo zlého prekladu, prebratej cudzojazyčnej informácie;

- Nepochopenie obsahu a zmyslu cudzojazyčného textu, $\mathrm{v}$ dôsledku čoho preklad zmení jeho pôvodný význam; Povrchne vykonaná korektúra rukopisu;

○ Štylistické nedostatky;

- Nesúlad medzi citáciami v texte a zoznamom bibliografických odkazov;

- Nedodržanie slovosledu vo viacslovných termínoch;

- Použitie nespisovných slov a termínov;

- Striedanie dvoch alebo troch alternatívnych metód citácie.

- Zaradenie prác, ktoré sa necitujú v texte do zoznamu bibliografických odkazov alebo naopak;

- Zmena obsahu pojmu spôsobená svojvol'ným vynechaním niektorého z prvkov viacslovného termínu;

- Nečitatel'ný popis na ploche obrázkov a schém;
- Nesprávne skloňovanie priezvisk viacerých tvorcov akoby išlo o jedného tvorcu so zloženým priezviskom;

- Absencia údaja o lokalizácií citovanej informácie alebo jeho nesprávny údaj;

- Citovanie ,z druhej ruky“, príp. „z n-tej ruky";

- Informačne zradné erráta, ktoré vedú $\mathrm{k}$ strate informácie;

- Neuvedenie zodpovednosti za preklad citovaných autentických cudzojazyčných informácií.

\section{Chyby a nedostatky, ktoré nevedú $k$ strate informácie}

Do tejto skupiny patria chyby a nedostatky, ktoré nevedú k strate informácie bud' preto, že sa mení len forma informácie alebo čitatel' si môže určit' správnu informáciu na základe kontextu. Aj v tomto prípade je spektrum možných chýb a nedostatkov vel'mi široké, preto uvedieme len niektoré typické príklady:

- Chaotické striedanie synonymných termínov prislúchajúcich tomu istému pojmu;

- Nekonzistentnost' zoznamu bibliografických odkazov (napr. nerovnaký počet nepovinných údajov v jednotlivých položkách zoznamu);

- Nedodržanie ustanovení štátnej normy (7) o pravidlách písania a úpravy písomností;

- Použitie homonymných termínov a termínových prvkov, skratiek, značiek a symbolov bez náležitého vysvetlenia;

- Duplicitné alebo viacnásobné uvádzanie tej istej informácie;

- Neuvádzanie iniciálok tvorcov v citáciách;

- Používanie zastaraných termínov;

- Neopodstatnené používanie vlastných neštandardnej definícií kl'účových pojmov, aj $\mathrm{v}$ prípade, ked' pojem je ustálený a štandardizovaný;

- Legenda k obrázku alebo fotografii nekorešponduje s ich obsahom;

- Narušenie postupnosti prirodzených čísel v prípade číselnej metóde citácií;

- Jazykové nedostatky v cudzojazyčnom abstrakte, resp. zhrnutí.

\section{Formálne chyby a nedostatky}

Do tejto skupiny možno zaradit' tie chyby a nedostatky, ktoré informačnú hodnotu prezentovaných informácií nemenia a týkajú sa najmä formy prezentovania informácií. Možno k nim zaradit' aj estetické nedostatky. Sú to napr.: 口 Zbytočne vel'ká medziriadková medzera; 
Nesúlad vel'kostí tabuliek, obrázkov, fotografií alebo schém;

$\square$ Nevyužite celej plochy obrázka alebo strany;

$\square$ Absencia medzier po interpunkčných znamienkach;

$\square$ Absencia medzier medzi hodnotou veličiny a jej jednotkou;

$\square$ Absencia rádovej medzery;

$\square$ Absencia bodky na konci dlhej vety obsahujúce výpočet viacerých položiek;

- Neopravené informačne nezradné erráta, v prípade ktorých čitatel' na základe kontextu spol'ahlivo určí, čo malo byt' uvedené na ich mieste;

๑ Nejednotné uvádzanie spôsobu odvodenia iniciálových skratiek alebo značiek;

$\square$ Striedanie formy toho istého termínu, skratky alebo značky;

$\square$ Použitie triviálnych názvov alebo obchodných názvov namiesto systémových termínov;

$\square$ Nedodržanie ustanovení štátnej normy (8) a (9) o forme biblografických odkazov a ich prvkov.

\section{Didaktické nedostatky}

$\mathrm{Na}$ nedostatky tohto typu je posudzovatel' povinný poukázat' len $\mathrm{v}$ prípade edukačne orientovaných prác. Typické nedostatky tejto skupiny predstavujú:

- Prevzatie definícií z odbornej needukačne orientovanej literatúry bez ich náležitej didaktickej transformácie;

- Narušenie zásady postupnosti;

-Narušenie medziodborových alebo medzipredmetových vzt'ahov;

- Nadmerné používanie cudzích slov a termínov;

- Neoptimálna vol'ba expozície osoby (napr. 1. osoby jednotného čísla) alebo jej neodôvodnené striedanie expozície;

- Nejednotná forma rovnocenných informácií.

- Používanie významovo nepriezračných alebo málo priezračných termínov v prípade, že existujú ich významovo priezračne priezračnejšie;

- Neposkytovanie informácií o existujúcich synonymných termínoch;

- Chaotické striedanie synonymných termínov $\mathrm{v}$ texte;

- Absencia nadväznosti jednotlivých zložiek textu;

- Vynechávanie iniciálok krstnych mien alebo chyby pri menách a priezviskách pôvodcov citovaných informácií;
- Neodôvodnené disproporcie v rozsahu, resp. nevyváženost' jednotlivých zložiek práce (napr. nadmerne rozsiahly úvod);

\section{Záver}

Každý kvalitne vypracovaný posudok odbornej alebo vedeckej práce predstavuje komplexnú nepublikovanú odbornú prácu, v ktorej posudzovatel' má podát' nielen vyvážený objektívny obraz o pozitívach i negatívach posudzovanej práce. Každý odborný posudok však podáva súčasne aj istú výpoved' o erudícii samého posudzovatel'a. Jednostranné zameranie len na klady, alebo len na nedostatky posudzovanej práce je $\mathrm{v}$ rozpore $\mathrm{s}$ pravidlami vedeckej etiky, nepomáha jej autorovi v jeho d'alšom odbornom raste a spochybňuje aj kompetenciu posudzovatel'a. Je neracionálne uvádzat' nedostatky a chyby v poradí ich výskytu bez prihliadania na ich závažnost'. Navrhované rozčlenenie zistených chýb a nedostatkov umožňuje oddelit' podstatné nedostatky a chyby od nepodstatných a v prípade obhajovaných prác aj upustit' od zbytočných časových strát pri čítaní všetkých zistených chýb a nedostatkov a obligatórnych odpovedí na ne.

\section{Zoznam bibliografických odkazov}

[1] STOFFOVÁ, V. Nedostatky kvalifikačných prác z informatiky - Ako zaviest', definovat' a používat' základné pojmy. In: DidInfo 2012 : Proceedings of abstracts and electronic versions of reviewed contributions on CD-ROM. Editori I. Kalaš a L.Huraj. Banská Bystrica: Univerzita Mateja Bela, Fakulta prírodných vied, 2012, s. 238 - 242. ISBN 978-80-557-0342-8

[2] STOFFA, J. - STOFFOVÁ, V. Nedostatky kvalifikačných prác - Čo je a ako má vyzerat' súčasný stav riešenej problematiky. In: DidInfo 2012 : Proceedings of abstracts and electronic versions of reviewed contributions on CD-ROM. Editori I.Kalaš a L.Huraj. Banská Bystrica: Univerzita Mateja Bela, Fakulta prírodných vied, 2012, s. 232 - 237 . ISBN 978-80-557-0342-8

[3] STOFFOVÁ, V. Nedostatky dizertačných prác v odbore Teória vyučovania informatiky. In. DidInfo 2011 : Proceedings of abstracts and electronic versions of reviewed contributions on CD-ROM. Editor G. Andrejková. Banská Bystrica: Univerzita Mateja Bela, Fakulta prírodných vied, 2011, s. 210 - 215 (abstrakt na s. 37). ISBN 978-80-557-0142-4 
[4] STOFFA, J. - STOFFOVÁ, V. Časté terminologické chyby v písomnej komunikácii z informačnej technológie. In: Zbornik : Sietové a informačné technológie : Celoškolský seminár. Nitra: Slovenská pol’nohospodárska univerzita, 2002, s. 104 - 108. ISBN 80-7137-981-6 [5] STOFFA, J. - STOFFOVÁ, V. Formálne a pseudoformálne chyby a nedostatky v edukačných dokumentoch. In: Trendy ve vzdělávání 2008 : Díl I. Editor Miroslav Chráska. 1. vyd. Olomouc: VOTOBIA Olomouc, 2008, s. 238 - 242. ISBN 978-80-7220-311-6

[6] STOFFA, J. Súčasný stav slovenskej technickej terminológie a terminológie didaktiky technických predmetov. In: ŠVEC, Š. a kol.: Jazyk vied o výchove. Bratislava: Gerlach print a Filolozofická fakulta Univerzity Komenského, 2002, s. 92 - 100. ISBN 80-968564-9-9

[7] STN 01 6910: December 1999, Pravidlá písania a úpravy písomností. 1. vyd. Bratislava: Slovenský ústav technickej normalizácie, 1998. $56 \mathrm{~s}$.
[8] ISO STN 390: Apríl 1998, Dokumentácia Bibliografické odkazy, Obsah, forma a štruktúra. 2. vyd. Bratislava: Slovenský ústav technickej normalizácie, 1998. $32 \mathrm{~s}$.

[9] ISO STN 390-2: December 2001, Informácie a dokumentácia, bibliografické citácie : Čast' 2: Elektronické dokumenty alebo ich časti. 1. vyd. Bratislava: Slovenský ústav technickej normalizácie - Vydavatel'stvo, 2001. $32 \mathrm{~s}$.

Prof. Ing. Ján Stoffa, DrSc., Univerzita J. Selyeho, Komárno e-mail: StoffaJan@seznam.cz Prof. Ing. Veronika Stoffová, Univerzita J. Selyeho, Komárno e-mail: NikaStoffova@seznam.cz 